\title{
Multiple Agents Rescue PC12 Cells from Serum-free Cell Death by Translation- and Transcription-independent Mechanisms
}

\author{
Adriana Rukenstein, ${ }^{1}$ Russell E. Rydel, ${ }^{3, a}$ and Lloyd A. Greene ${ }^{1,2}$ \\ 'Department of Pathology and ${ }^{2}$ Center for Neurobiology and Behavior, Columbia University College of Physicians and \\ Surgeons, New York, New York 10032 and ${ }^{3}$ Department of Pharmacology, New York University School of Medicine, \\ New York, New York 10016
}

Past studies revealed that NGF and fibroblast growth factor (FGF) prevent the death of PC12 pheochromocytoma cells that otherwise occurs in serum-free medium. Additional agents were tested here for their abilities to promote longterm survival of naive and NGF-pretreated (primed) PC12 cells in serum-free conditions. Forskolin and permeant CAMP analogs effectively prevented serum-free cell death, as did micromolar levels of insulin and 10-100-nM levels of insulinlike growth factors I and II. In contrast to NGF and FGF, none of these agents caused neuronal differentiation of naive cells or neurite regeneration by primed cells. Each of the agents also prevented rapid cell death in a balanced salt solution, thus apparently ruling out a mechanism dependent on regulation of nutrient uptake. Epidermal growth factor and elevated $\mathrm{K}^{+}$appeared to slow the rate of cell death, but did not promote long-term survival; phorbol ester, dexamethasone, or vanadate did not prevent cell death. Each of the survival-promoting agents was effective even when macromolecular synthesis was blocked. Because the synthesis inhibitors themselves did not significantly prevent cell death, such findings indicate that survival was promoted by mechanisms that do not require synthesis of RNA or protein. In addition, various lines of experimental evidence (using the kinase inhibitor K-252a or PC12 cell variants deficient either in protein kinase $A$ activity or in responsiveness to NGF) further suggested that the effective agents maintain survival by independent initial pathways. Regulation of protein kinase activity appears to be a common feature of each pathway and may therefore play a key convergent role in mediating prevention of cell death.

Among the major actions of trophic agents is the maintenance of cell survival/prevention of cell death. For instance, in the nervous system, both in vitro (Levi-Montalcini and Angeletti, 1963) and in vivo (Levi-Montalcini and Booker, 1960; Gorin and Johnson, 1979) experiments have revealed that NGF is required for the survival of sympathetic and developing sensory neurons. While inroads are being made on this issue (Martin et

\footnotetext{
Received Jan. 21, 1991; revised Mar. 11, 1991; accepted Mar. 13, 1991.

This work was supported by grants from the U.S. Public Health Service (NIH) and from the Familial Dysautonomia Foundation.

Correspondence should be addressed to Lloyd A. Greene, Department of Pathology, Columbia University College of Physicians and Surgeons, 630 West 168 th Street, New York, NY 10032.

aPresent address: Athena Neurosciences, $800 \mathrm{~F}$ Gateway Boulevard, South San Francisco, CA 94080.
}

Copyright (C) 1991 Society for Neuroscience $0270-6474 / 91 / 112552-12 \$ 03.00 / 0$ al., 1988; Koike et al., 1989; Oppenheim et al., 1990), the mechanism whereby NGF and other agents promote neuronal survival is presently unclear.

We and others have employed the PC12 line of rat pheochromocytoma cells to study the mechanisms of NGF action and as a model for various aspects of neuronal behavior (Greene and Tischler, 1976, 1982; Levi et al., 1988). PC12 cells have been especially useful for this because they respond to NGF by undergoing morphological and biochemical differentiation similar to that shown by maturing sympathicoblasts. With respect to the subject of NGF-dependent survival, PC12 cells differ from sympathetic neurons in that they survive without NGF if cultured in presence of serum (Greene and Tischler, 1976). However, in a serum-free nutrient medium such as RPMI 1640, PC1 2 cells rapidly die unless NGF is present (Greene, 1978). Subsequent studies have shown that fibroblast growth factor (FGF), an agent with trophic actions on certain neurons (Morrison et al., 1986; Walicke et al., 1986) and on PC12 cells (Togari et al., 1985; Rydel and Greene, 1987), can also rescue PC12 cells from serum-free cell death (Rydel and Greene, 1987). Findings of this type have suggested that PC12 cells may be utilized in the serum-free paradigm to study the mechanisms by which neuronal survival and cell death are regulated.

The present study addresses several issues related to the subject of cell survival. First, we have asked what agents in addition to NGF and FGF may promote PC12 cell survival in a defined medium and what these agents may share in common with respect to possible mechanism. In addition, we have defined agents that fail to support $\mathrm{PCI} 2$ cell survival and thereby have ruled out certain mechanistic pathways. Further experiments deal with the issue of whether macromolecular synthesis is required for the survival-promoting actions of NGF and other factors. Finally, our data permit comparison of NGF-deprived sympathetic neurons and serum-deprived PC12 cells.

\section{Materials and Methods}

Materials. NGF was prepared from male mouse submaxillary glands as previously described (Mobley et al., 1976). Bovine brain basic FGF (bFGF), insulin-like growth factors I and II (IGF-I and IGF-II), dibutyryl cyclic AMP, and 8-(4-chlorophenylthio) cyclic AMP (CPT-CAMP) were purchased from Boehringer-Mannheim. Insulin, dcxamcthasonc, actinomycin, forskolin, phorbol 12-myristate 13-acetate (PMA), anisomycin, and camptothecin were purchased from Sigma Chemical Company. K-252a was the kind gift of Dr. Gordon Guroff, National Institutes of Health.

Cell culture. Stock PC12 cultures (passages 26-31) were maintained as previously described (Greene and Tischler, 1976, 1982) in RPMI 1640 medium supplemented with $10 \%$ heat-inactivated horse serum and $5 \%$ fetal bovine serum. For serum-free experiments, the cells in 
stock cultures were washed three or four times with serum-free RPMI 1640 medium (supplemented with $50 \mathrm{U} / \mathrm{ml}$ of penicillin and $50 \mu \mathrm{g} / \mathrm{ml}$ streptomycin). The cells were then detached from the dishes by repeated trituration and washed again in serum-free medium by three to five cycles of centrifugation/resuspension. The washed cells were resuspended in RPMI 1640 medium and plated at a density of $2-6 \times 10^{4}$ cells per well in 24-well $(16-\mathrm{mm}$ diameter) plastic culture dishes. The bottom surfaces of the wells were precoated with rat-tail collagen as described elsewhere (Greene and Tischler, 1982), and the volume of medium per well was $0.5 \mathrm{ml}$. For experiments involving "primed" PC12 cells, cultures were treated for 1-2 weeks with NGF in RPMI 1640 medium supplemented with $1 \%$ heat-inactivated horse scrum. The cells were then passaged into serum-free medium as described above, except that six washes by centrifugation/resuspension were used to enhance removal of residual NGF. The medium in all serum-free cultures was replaced every $3-4 \mathrm{~d}$.

The A126-1B2 variant line of PC12 cells (Van Buskirk et al., 1985) was kindly provided by Dr. John Wagner, Harvard Medical School. The UR61 line of N-ras-inducible U7 cells (a PC12 cell variant; Guerrero et al., 1988) was kindly provided by Dr. David Burstein, Mt. Sinai School of Medicine. Both lines, as well as PC12nnr 5 cells (Green et al., 1986) were cultured and treated as described for PC12 cells.

When various agents were supplied to the serum-free cultures, these were added from 10-1000-fold concentrated stocks, except for $\mathrm{KCl}$, for which additions were made by mixing RPMI 1640 with the appropriate amounts of a $160-\mathrm{mm}$ solution of $\mathrm{KCl}$.

Cell counts. For cells growing in multiwell dishes, the culture medium (along with most cellular debris) was removed by aspiration and replaced with $0.5 \mathrm{ml}$ of a detergent-containing lysing solution that dissolves cell membranes and cytoplasm and that provided a uniform suspension of single, intact nuclei (Soto and Sonnenschein, 1985). The latter were quantified by counting in a hemacytometer. Broken or damaged nuclei were not included in the counts. In all cases, triplicate wells were scored, and counts are presented as means \pm SEM.

There was only a minimal change in cell number in the NGF-treated serum-free cultures over time (recoveries ranged between $94 \%$ and $125 \%$ of cells plated by up to 1 week), probably because of the stringent washing procedures used to remove bound serum components. Likewise, both counts and the absence of debris generated by cell death indicated little loss of cells in the NGF-treated cultures over the course of the experiments. For this reason, and to permit convenient comparison of data from different experiments, results are presented relative to cell numbers in NGF-treated cultures rather than in absolute cell numbers.

\section{Results}

Multiple agents support PC12 cell survival in serum-free medium. Past studies showed that PC12 cells degenerate within a few days of culture in serum-free medium (Greene, 1978) and that NGF (Greene, 1978) and FGF (Rydel and Greene, 1987) support their long-term survival under such conditions. A variety of additional agents to which $\mathrm{PC} 12$ cells are known to respond were tested for their capacities to maintain the cells in serum-free RPMI medium for 1 week. Without additives, essentially all of the cells were dead by this time, whereas all survived in the presence of NGF (Figs. 1,2). Figures 1 and 2 show that 8-(4-chlorophenylthio) cAMP promotes long-term survival of the cells with a maximal effect at about $100 \mu \mathrm{M}$. Dibutyryl cAMP (not shown) and forskolin, an activator of adenylate cyclase (Fig. 2) also effectively prevented cell death.

As shown in Figure 2, insulin is an additional agent that promotes PC1 2 cell survival. Maximal activity occurred at about $3 \mu \mathrm{M}$, a concentration far higher than that required for other direct actions of this hormone. This suggested that insulin might be acting via receptors for IGF-I and/or IGF-II. Also, functional receptors for IGFs have becn demonstrated on PC1 2 cells (Dahmer and Perlman, 1988; Nielsen and Gammeltoft, 1988; Dahmer et al., 1989). In consonance with this, both IGFs supported PC12 cell survival and did so at concentrations of 10-100 nM (Figs. 1,2). Insulin and the IGFs also promoted at least a degree of cell division under the serum-free conditions because the cell number at 1 week was in each case higher than the number initially plated. Visual inspection of cultures indicated that the cAMP analogs, insulin and the IGFs (in addition to NGF and FGF), maintained survival for at least 2 weeks under the serumfree conditions. However, in contrast to NGF, the other agents did not cause morphological differentiation (Fig. 1).

Agents that do not support long-term survival. A variety of additional substances that have been identified as promoters of cell or neuronal survival in other systems were also tested in the serum-free paradigm. Epidermal growth factor (EGF), which can support survival of certain CNS neurons (Morrison et al., 1987) and for which PC12 cells bear receptors and responses (Huff et al., 1981; Lazarovici et al., 1987), exerted a relatively small effect on long-term survival (Figs. 1, 3). Inspection of the cultures at times shorter than 1 week revealed that, though EGF did not ultimately prevent cell death, it did slow the rate of cell loss (data not shown). The small number of cells that were present after 1 week with EGF did not appear to constitute a responsive subpopulation because essentially no cells survived in the presence of this factor by 2 weeks of treatment.

PMA, a tumor promoter and potent activator of protein kinase $C$, has been reported to maintain the survival of chick peripheral neurons (Montz et al., 1985). In contrast, when tested over a wide range of concentrations, it did not support longterm PC12 cell viability (Fig. 3), nor did it prevent cell death at very early times of culture (data not shown). Moreover, it did not substantially diminish the ability of NGF to prevent cell death, even at concentrations up to $10 \mu \mathrm{M}$.

Prolonged exposure to depolarizing levels of $\mathrm{K}^{+}$has been recognized as an effective means to prevent the death of a variety of neuronal types, including sympathetic neurons (Wakade et al., 1983; Koike et al., 1989). Iowever, as shown in Figures 1 and 3 , this treatment was relatively ineffective in promoting PC1 2 cell survival for 1 week; after 2 weeks, no survival was apparent (data not shown). Like EGF, elevated $\mathrm{K}^{+}$appeared to somewhat delay, rather than prevent cell death. The data in Figure 3 show that high $\mathrm{K}^{+}$concentrations also somewhat diminished the survival effects of NGF.

In addition to the above agents, dexamethasone also was unable to prevent PC12 cell death. Glucocorticoids have been shown to antagonize a variety of NGF actions (Doupe et al., 1985; Leonard et al., 1987) but, except at a very high concentration, did not significantly reduce the survival-promoting actions of NGF (Fig. 3). Instances have been reported in which the application of vanadate (Rawson et al., 1990) prevents cell death, presumably by inhibition of phosphotyrosine phosphatase activities. However, this agent, at concentrations from 0.1 nM to $1 \mu \mathrm{M}$, did not prevent PC1 2 cell death (data not shown).

Survival effects on "primed" PC12 cells. The above experiments were performed on PC.12 cells that had no prior exposure to NGF. Because NGF treatment can substantially alter cellular properties, experiments were performed in which cultures were preexposed to NGF for 1-2 weeks in the presence of serum to permit neuronal differentiation (i.e., primed; Burstein and Greene, 1978) and then detached from the substrate and passaged into serum-free medium with NGF or the various treatments described above. After $4 \mathrm{~d}$, numbers of surviving cells were assessed. The data in Figures 4 and 5 show that removal of serum and NGF resulted in a substantial degree of cell loss. In contrast, NGF supported both serum-free cell survival and neurite regeneration; FGF also supported survival and, as pre- 

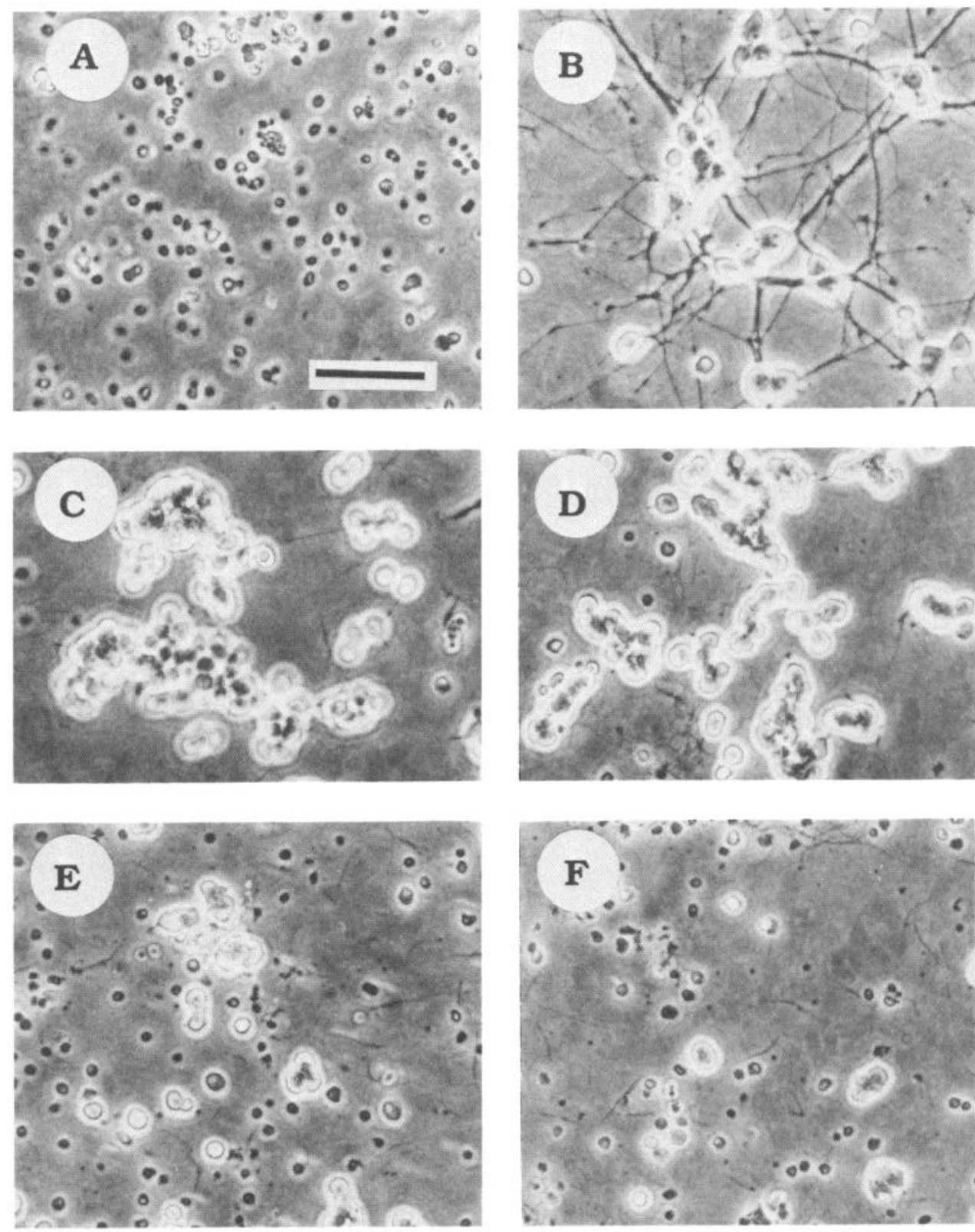

Figure 1. Morphology of $\mathrm{PC} 12$ cells maintained for 1 week in serum-free RPMI 1640 medium supplemented with various agents: no additives $(A)$ $50 \mathrm{ng} / \mathrm{ml} \mathrm{NGF}(B), 100 \mu \mathrm{M}$ CPT-cAMP $(C), 10$ nм IGF-I $(D), 1.3$ nм EGF $(E)$ or $43 \mathrm{~mm} \mathrm{~K}^{+}(F)$. Cells were washed and plated in RPMI 1640 medium as described in Materials and Methods. Phase-contrast optics. Scale bar, $50 \mu \mathrm{m}$.

viously reported (Togari et al., 1985; Rydel and Greene, 1987), a degree of process outgrowth. CPT-cAMP, insulin, IGF-I, and IGF-II, as with naive cells, maintained survival of the primed cells, but did not promote significant levels of neurite regrowth (Figs. 4, 5). Furthermore, EGF and elevated $\mathrm{K}^{+}$, as with naive cells, did not provide robust support of the primed cells (Figs. $4,5)$.

Role of RNA transcription and protein synthesis in prevention of cell death. The abilities of the various agents to promote survival were tested in the presence of high concentrations of inhibitors of protein and RNA synthesis. The inhibitors were applied $0.5-1 \mathrm{hr}$ prior to the survival factors, and the cultures were evaluated for cell number 16-20 hr later. Under these conditions, approximately $60-90 \%$ of the cells die in serum-free medium alone. At the concentrations employed, actinomycin and camptothecin inhibit PC12 cell RNA synthesis by approximately $95 \%$ and $85 \%$ (Burstein and Greene, 1978), respectively, and anisomycin inhibits $\mathrm{PC} 12$ cell protein synthesis by over 99\% (Greenberg et al., 1986). The data in Figures 6 and 7 show that the inhibitors did not substantially block the capacities of the various agents tested (NGF, CPT-cAMP, insulin, IGF-I, and IGF-II) to rescue the cells from death. Similar results were obtained with "primed" cells (data not shown).

The inhibitors of macromolecular synthesis were also tested in the absence of survival agents. At the concentrations used above, the inhibitors did not show substantial rescue of either naive (Fig. 6) or primed cells (not shown) from death. This was also the case when the inhibitors were tested at serial dilutions (by factors of one-third) down to 100-fold lower concentrations.

Promotion of survival in nutrient-free medium. One potential mechanism for the promotion of cell survival/prevention of cell death is regulation of the uptake of required nutrients from extracellular sources (Horii and Varon, 1977). To test this, cells were plated in serum-free Hank's balanced salt solution with or 

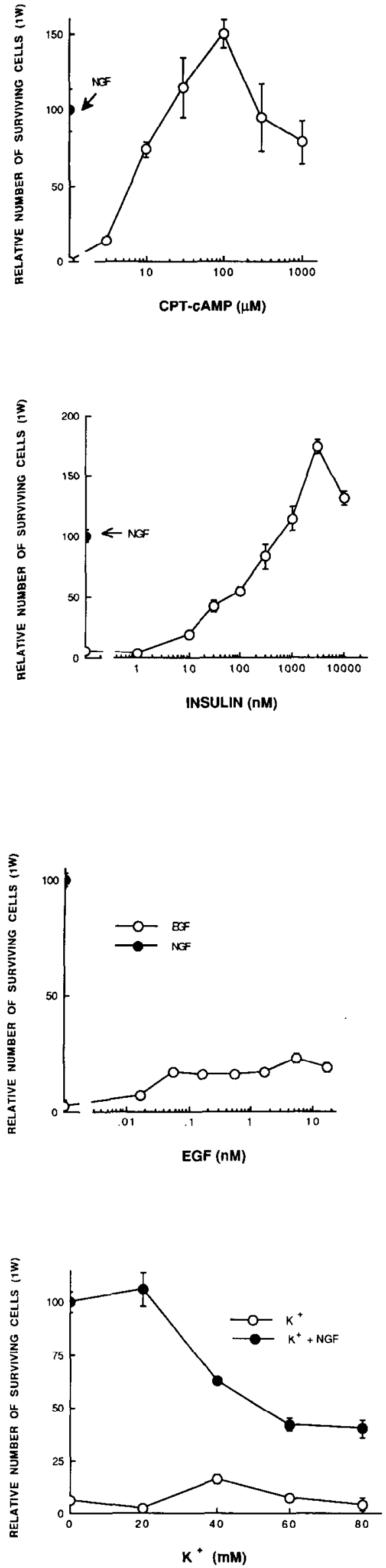
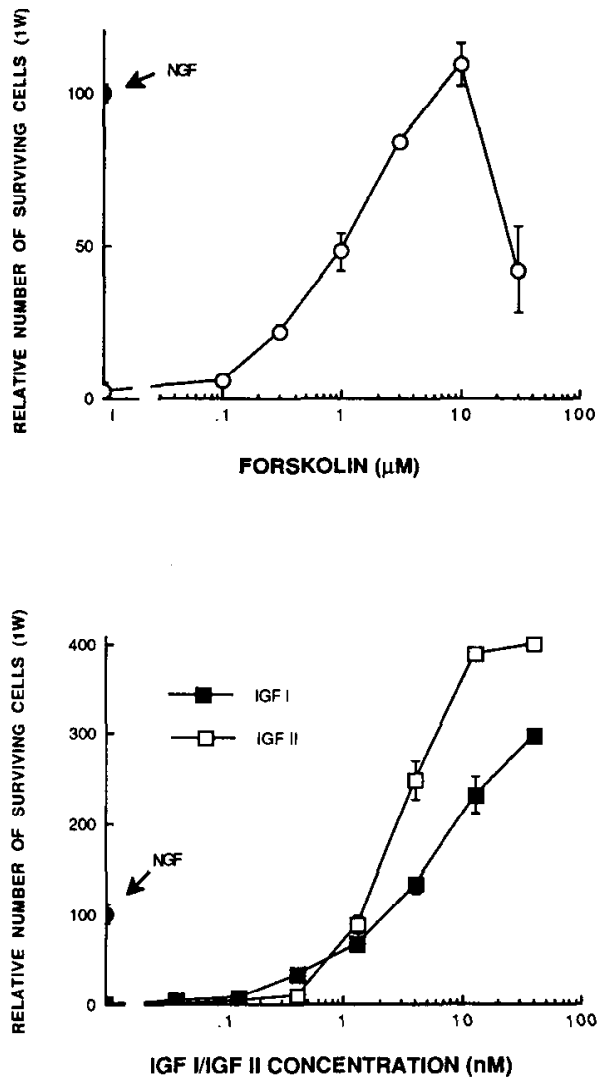

Figure 2. Dose-response relationships for 1-week survival of PC12 cells in serum-free RPMI 1640 medium supplemented with the indicated additives (CPT-cAMP, forskolin, insulin, IGF-I, or IGF-II). Cell survival data are expressed relative to that in NGF-treated sister cultures (indicated by arrows). Recoveries in the NGF-treated cultures ranged between $96 \%$ and $114 \%$ of the numbers of cells originally plated. Error bars represent SEM $(n=3)$.
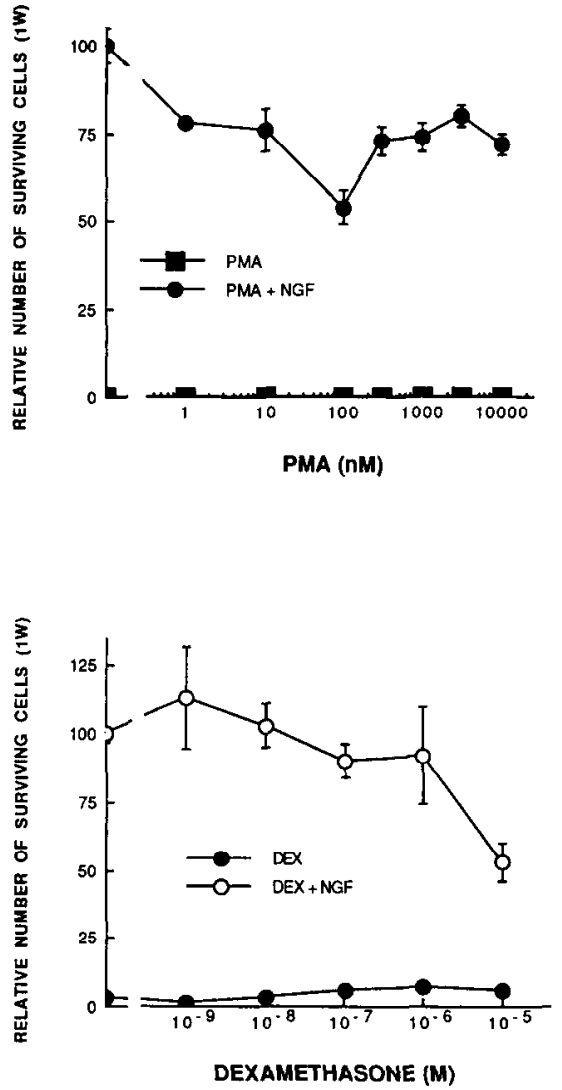

Figure 3. Dose-response relationships for 1-week survival of PC12 cells in serum-free RPMI medium supplemented with the indicated additives (EGF, PMA, KCI, or dexamethasone) and with or without NGF. Cell survival data are expressed relative to that in sister cultures treated with NGF alone. Error bars represent SEM $(n=3)$. 

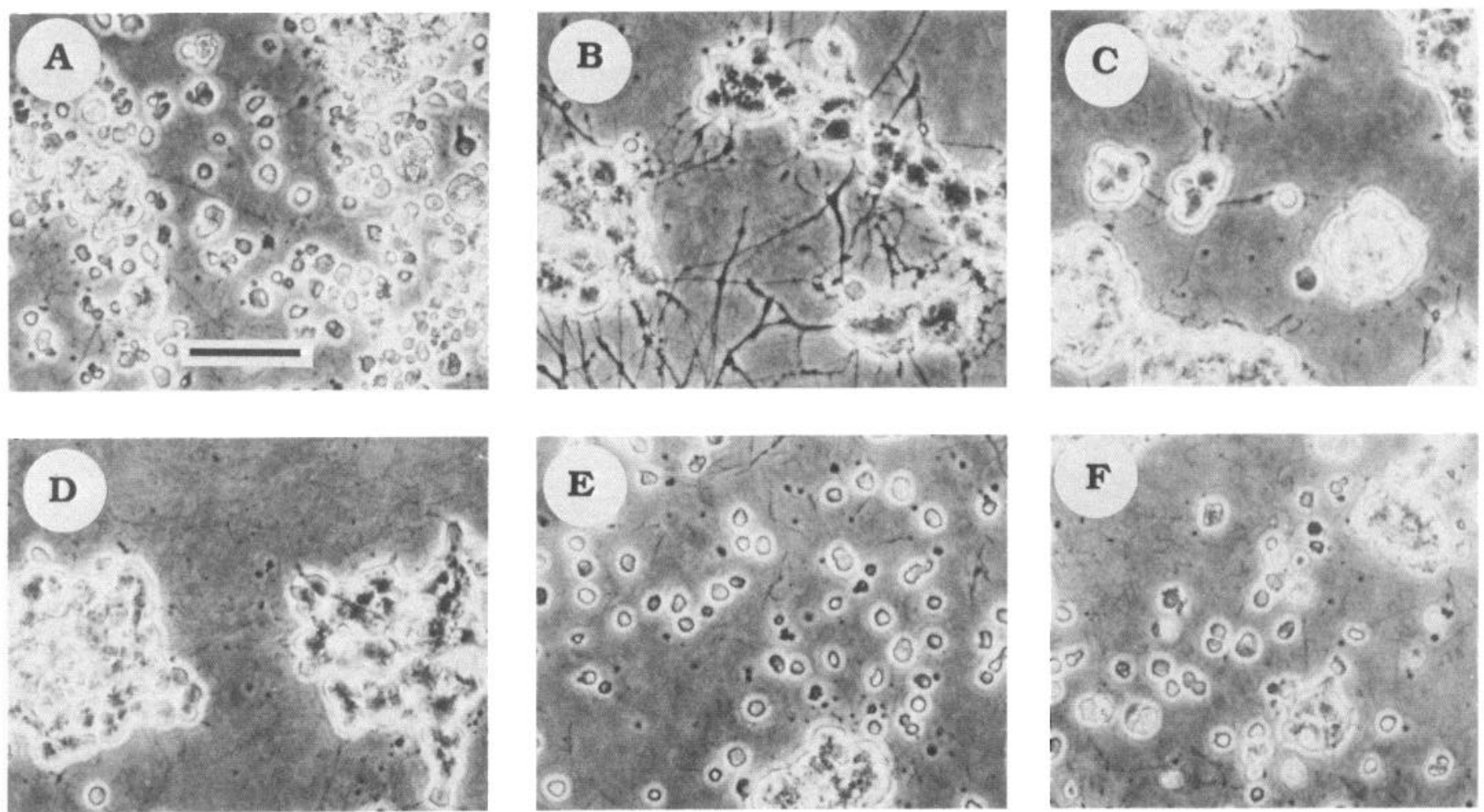

Figure 4. Morphology of NGF-pretreated PC12 cells maintained for $4 \mathrm{~d}$ in serum-free RPMI 1640 medium with no additive $(A)$, NGF $(B)$, 100 $\mu \mathrm{M}$ CPT-cAMP $(C), 3 \mu \mathrm{M}$ insulin $(D), 43 \mathrm{~mm} \mathrm{~K}^{+}(E)$, or $1.3 \mathrm{~nm}$ EGF $(F)$. Cells were pretreated with NGF in serum-containing medium for $8 \mathrm{~d}$, then washed and passaged into RPMI medium and maintained for $4 \mathrm{~d}$ with the indicated additives as described in Materials and Methods. Phasecontrast optics. Scale bar, $50 \mu \mathrm{m}$.

号

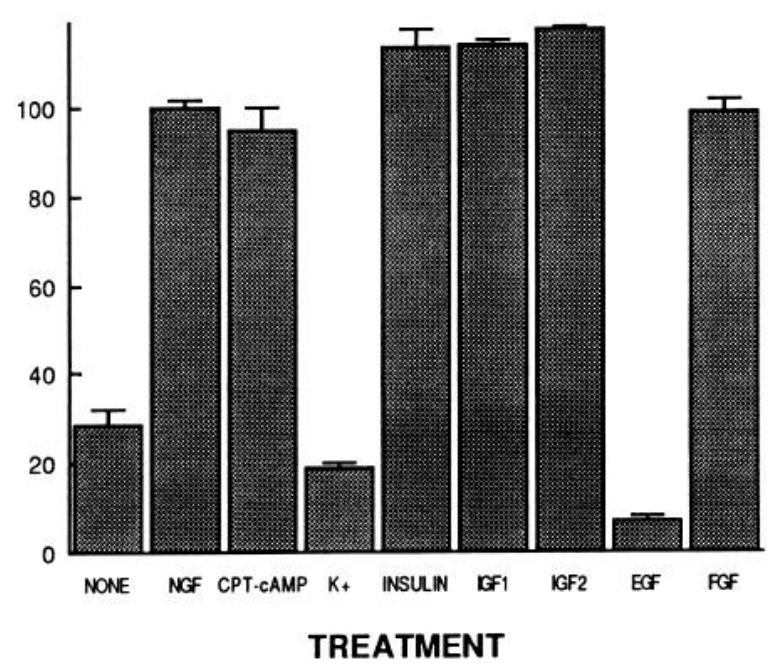

Figure 5. Survival of NGF-pretreated (primed) cells maintained in serum-free medium for $4 \mathrm{~d}$ in presence of the indicated additives. Cells were pretreated with NGF in serum-containing medium for $8 \mathrm{~d}$, then washed and passaged into RPMI medium and maintained for $4 \mathrm{~d}$ with the indicated additives as described in Materials and Methods. Cell numbers are expressed relative to those in cultures treated with NGF. Recovery of the latter averaged $94 \%$ of the number of cells plated. Concentrations were NGF, 2 nм; CPT-cAMP, $100 \mu \mathrm{M} ; \mathrm{K}^{+}, 43 \mathrm{~mm}$; insulin, $3 \mu \mathrm{M}$; IGF-I and IGF-II, $10 \mathrm{~nm}$; EGF, $1.3 \mathrm{~nm}$; FGF, $10 \mathrm{~nm}$. Error bars represent SEM $(n=3)$. without various agents and counted $1 \mathrm{~d}$ later. Without additives, $60-95 \%$ of the cells died; good survival was apparent, however, when NGF, FGF, insulin, IGF-I, IGF-II, CPT-cAMP, or forskolin were present (Fig. 8). These agents maintained survival for 2-3 d before cell death occurred, presumably because of the absence of essential nutrients. EGF and elevated $\mathrm{K}^{+}$showed partial prevention of cell death at $24 \mathrm{hr}$ (Fig. 8). This appears to be consistent with their delay, rather than prevention, of cell death. These data thus suggest that the agents tested here do not promote cell survival by controlling the uptake of metabolites from the extracellular environment.

Potential role of protein kinases $A$ and $C$ in prevention of cell death. The observation that cAMP analogs prevent PC12 cell death suggests a potential role for protein kinase $A$ in this action. To test this, as well as the possible role of PKA in the survival action of other agents, the A126-1B2 line, a variant of PC12 cells that is defective in PKA activity (Van Buskirk et al., 1985), was employed. The data in Figure 9 show that CPT-cAMP was ineffective in promoting survival of A126-1B2 cells; this strongly suggests that activation of PKA is involved in the maintenance of serum-free cell survival by cAMP analogs. In contrast to CPT-cAMP, NGF, insulin, IGF-I, IGF-II, and FGF all promoted long-term survival of A126-1B2 cells in serum-free medium. Such findings indicate that PKA neither mediates nor is required for the survival actions of these growth factors.

With regard to PKC, the above findings that PMA does not promote cell survival indicate that activation of this kinase is 

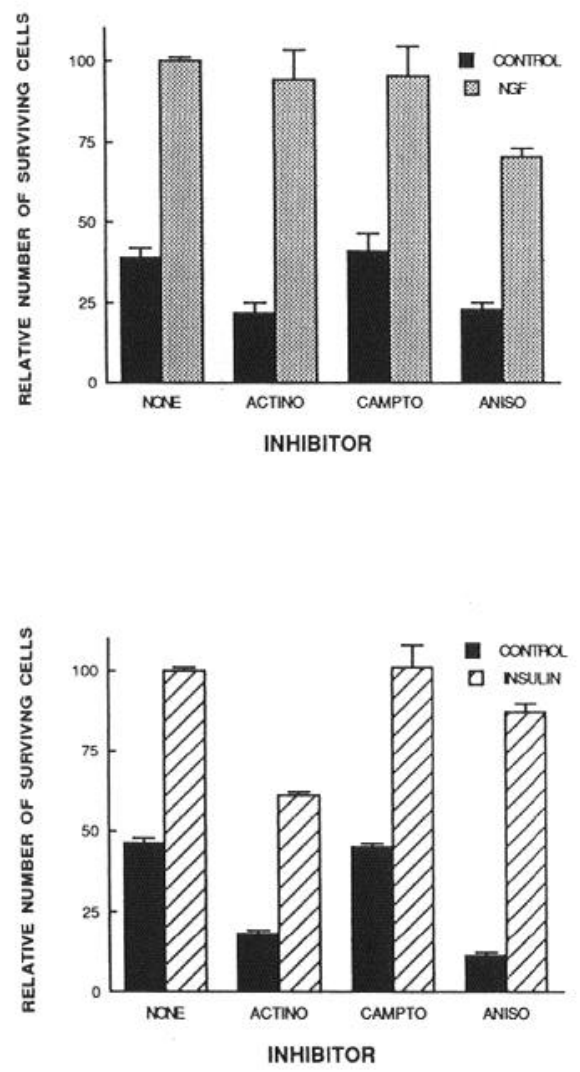
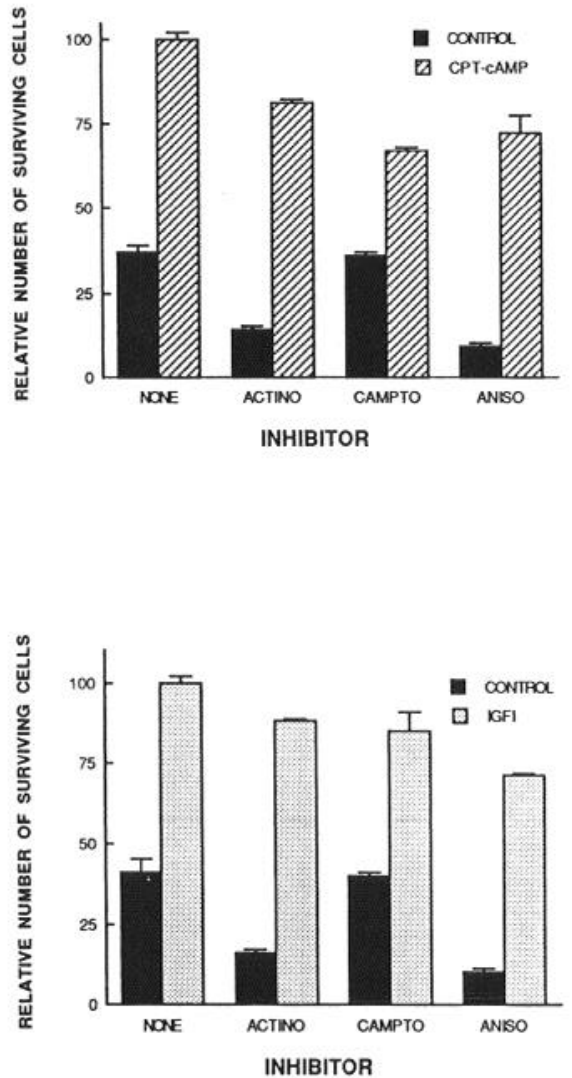

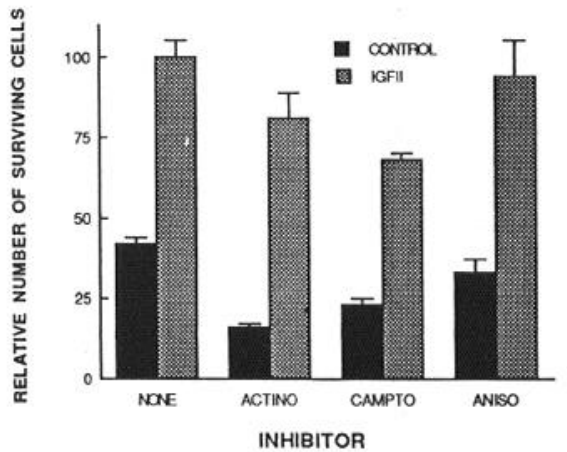

Figure 6. Effects of macromolecular synthesis inhibitors on the capacities of NGF $(2 \mathrm{~nm})$, CPT-cAMP $(100 \mu \mathrm{M})$, insulin $(3 \mu \mathrm{M})$, and IGF-I and IGF-II (each $10 \mathrm{~nm}$ ) to promote PC12 cell survival in serum-free RPMI 1640 medium. Cells were washed and plated in RPMI 1640 medium and pretreated where indicated for $2 \mathrm{hr}$ with $10 \mu \mathrm{M}$ actinomycin-D (ACTINO), $20 \mu \mathrm{M}$ camptothecin (CAMPTO), or $100 \mu \mathrm{M}$ anisomycin (ANISO), and then with or without the indicated growth factors for an additional $16-20 \mathrm{hr}$. Cell numbers are expressed relative to those in cultures treated with each factor alone. Error bars represent SEM $(n=3)$. not sufficient to prevent serum-free cell death. To explore further the role of $\mathrm{PKC}$ in survival, serum-containing $\mathrm{PC} 12$ cultures were pretreated with $5 \mu \mathrm{M}$ PMA for $3 \mathrm{~d}$ and then exposed to $\mathrm{NGF}$, insulin, or CPT-cAMP in serum-free medium with or without the continued presence of the phorbol ester. Prior experiments have established that exposure of $\mathrm{PC1} 2$ cells to such concentrations of PMA leads to a substantial downregulation of their PKC levels (Matthies et al., 1987). The data in Figure 9 show that, despite this treatment, each of the tested agents retained the capacity to prevent cell death. This suggests that PKC also neither mediates nor is required for the survivalpromoting actions of NGF, CPT-cAMP, or insulin.

Differential actions of $K-252 a$ on survival. The drug K-252a has been shown at low concentrations $(200 \mathrm{~nm})$ to block a variety of actions of NGF on PC12 cells, but not to effect at least certain responses to FGF and other agents (Koizumi et al., 1988). The data in Figure 10 show that 200 nм K-252a itself does not affect the course of serum-free cell death and that it does completely suppress the ability of NGF to maintain survival. In contrast, the drug did not block the survival-promoting actions of CPTcAMP, insulin, IGF-I, IGF-II, or FGF.

Promotion of survival by expression of $N$-ras. The expression of $\mathrm{v}$-ras or $\mathrm{N}$-ras in serum-supported $\mathrm{PC} 12$ cells leads to process outgrowth and other manifestations of neuronal differentiation (Noda et al., 1985; Guerrero et al., 1986). It has been suggested that cellular ras protein may be involved in the primary mechanism of action of NGF (Hagag et al., 1986). Furthermore, injection of oncogenic ras protein into a variety of chick embryo peripheral neuron types promotes their survival in vitro (Borasio et al., 1989). To test the potential effect of ras expression in the 

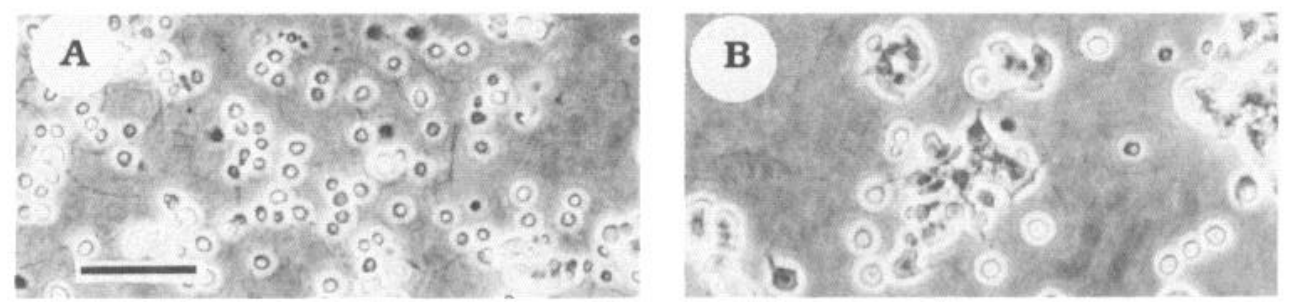

Figure 7. Morphology of $\mathrm{PC} 12$ cells maintained in serum-free RPMI 1640 medium for $1 \mathrm{~d}$ with either no additives $(A), \operatorname{NGF}(B), 10 \mu \mathrm{M}$ actinomycin-D $(C)$, or NGF plus $10 \mu \mathrm{M}$ actinomycin-D $(D)$. Cells were washed and plated in medium and pretreated for $2 \mathrm{hr}$ where appropriate with actinomycin before NGF addition. Phase contrast optics. Scale bar, $50 \mu \mathrm{m}$.
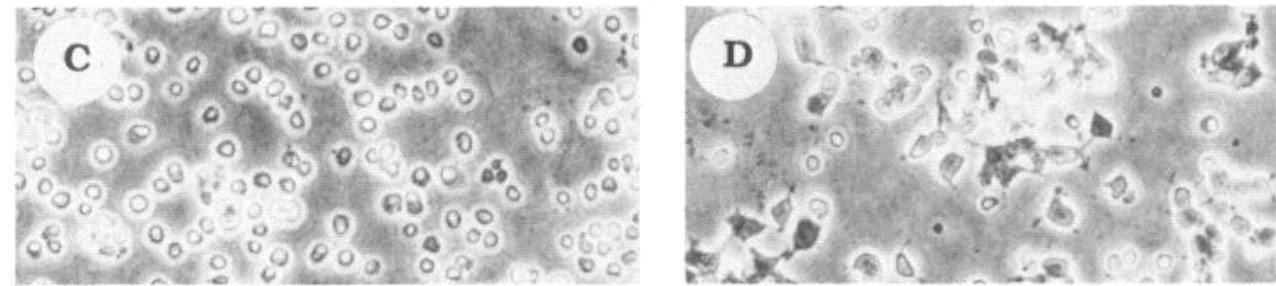

present serum-free paradigm, experiments were performed using the UR61 cell line. The latter is derived from a variant line of $\mathrm{PC} 12$ cells and possesses a dexamethasone-inducible N-ras (Guerrero et al., 1988). UR61 cells were preexposed in serumcontaining medium to $1 \mu \mathrm{M}$ dexamethasone for $5 \mathrm{~d}$ to induce $\mathrm{N}$-ras and then passaged into serum-free medium for $4 \mathrm{~d}$ with or without NGF. For dexamethasone-pretreated cells, the corticosteroid was also present during culture in serum-free medium. The data in Figure $11 A$ show that dexamethasone treatment promoted survival to a degree similar to that achieved with NGF. Because dexamethasone itself does not prevent serum-free cell death (Fig. 3), these findings show that induction of $\mathrm{N}$-ras promotes cell survival. Figure $11 B$ shows the effect of $\mathrm{K}-252 \mathrm{a}$ on serum-free survival by ras-induced UR61 cells. In contrast to its effects on NGF-promoted survival, K-252a did not significantly diminish the ability of ras to prevent cell death. This suggests that, if ras proteins were to play a role in the NGF mechanism of survival promotion, then they would do so at steps downstream from the step affected by K-252a.

Promotion of survival of PC12 cell variants lacking high-affinity $N G F$ receptors. $\mathrm{PC} 12 \mathrm{nnr} 5$ cells are a variant line with lowbut not high-affinity NGF receptors (Green et al., 1986). These cells cannot endocytose NGF and lack a variety of responses to NGF, including the capacity to be maintained in serum-free medium (Green et al., 1986). The data in Figure 12 confirm the lack of survival response to NGF and show that, despite this, FGF, insulin, and CPT-cAMP can each prevent serum-free cell death of the variant cells. These findings indicate that the defective element in the variants that otherwise confers NGF receptor functionality does not play a required role in the mechanisms by which FGF, insulin, and cAMP derivatives prevent cell death.

\section{Discussion}

This study has explored several aspects of the mechanisms by which trophic agents prevent cell death of neuronal-like PC12 cells in a controlled milieu. We have used these cells both before and after NGF-promoted neuronal differentiation and, in each case tested, found comparable results. In part because PC12 cells share a number of properties in common with sympathetic neurons and their precursors (Greene and Tischler, 1976, 1982), one aim here has been to examine the suitability of this model for extending neuronal cell death studies. Our findings suggest both similarities to and differences from normal neuronal behavior.

Multiple agents and multiple primary mechanisms support survival. The paradigm used here has been to test various agents for their abilities to rescue $\mathrm{PC} 12$ cells from death brought about by serum deprivation. Exposure of $\mathrm{PC} 12$ cells to serum-free medium can be viewed as withdrawal of trophic agents. Unlike sympathetic neurons, $\mathrm{PC} 12$ cells can survive in presence of serum. This most likely is due to their capacity to respond to serum-borne trophic agents, and this in turn probably reflects the immature/neoplastic nature of pheochromocytoma cells. For instance, though mature sympathetic neurons do not respond to FGF, both sympathico-adrenal precursors (Stemple et al., 1988 ) and PC12 cells do. Thus, our assay system may reveal defined agents that either normally act as neurotrophic factors or that ultimately mimic the mechanistic actions of such molecules.

Past work established that NGF and FGF provide long-term rescue of PC12 cells after serum deprivation. These factors also induce $\mathrm{PC} 12$ cell neuronal differentiation. Among the present findings is that several agents that do not promote the differentiation of PC12 cells, namely, insulin and IGFs as well as mimics or inducers of intracellular cAMP, will also rescue them from death. There is precedence for these results. PC12 cells have other known responses to each of the death-prevention agents (Greene and Tischler, 1982; Togari et al., 1985; Dahmer and Perlman, 1988; Nielsen and Gammeltoft, 1988; RowlandGagné and Greene, 1990). Furthermore, the survival-promoting actions of NGF and FGF on various types of neurons have been well documented (cf. Morrison et al., 1986; Walicke et al., 1986; Knusel et al., 1990), and there is evidence for similar effects of insulin, IGFs, and cAMP derivatives (cf. Aizenman and de Vellis, 1987; Gammeltoft et al., 1988; Knusel et al., 1990). With respect to sympathetic neurons, NGF (Levi-Montalcini and Angeletti, 1963), insulin (Recio-Pinto et al., 1986), cAMP derivatives (Rydel and Greene, 1988), and vasoactive intestinal peptide (probably via cAMP; Pincus et al., 1990) may each sustain their survival in vitro.

It is notable that the various survival-promoting activities described here employ distinct primary mechanisms of action. For instance, our data indicated that the survival-promoting activity of CPT-cAMP was mediated by protein kinase A, but that such actions of NGF, FGF, insulin, and the IGFs were not. 
Similarly, both NGF and CPT-cAMP can maintain rat sympathetic neuron survival in culture, but only in the latter case is activation of PKA required (Rydel and Greene, 1988). In the cases of FGF, insulin, and the IGFs, it is likely that primary mediation involves specific receptor-associated tyrosine kinase activities (Czech, 1989; Lee et al., 1989; O'Hare and Pilch, 1990). NGF also appears to trigger rapid changes in PC12 cell protein phosphotyrosine levels (Maher, 1988). However, despite this as well as the observation that many FGF and NGF actions on PC1 2 cells are comparable, as in other instances (Koizumi et al., 1988), the protein kinase inhibitor K-252a differentially blocked the supportive actions of NGF, but not those of FGF (or of other agents). Moreover, an NGF-insensitive PC12 cell variant line retained survival responses to FGF, insulin, and CPT-cAMP. These findings all indicate that various independent initial pathways may be employed to prevent cell death in PC12 cells.

While the full mechanisms are unknown by which survival is promoted by each of the agents described here, it is worth noting that each regulates specific cellular phosphorylations in target cells. This raises the speculation that phosphorylation may be the critical regulatory event in control of cell survival/death. A further speculation is that, while various agents may use different primary mechanistic pathways, each may convergently prevent cell death by regulating phosphorylation of the same key substrates.

Agents that do not rescue PC12 cells from cell death. Although several different agents maintained PC12 cell survival, the lack of effect of certain other treatments is informative. PMA neither prevented cell death nor interfered with NGF-promoted survival. Moreover, NGF was effective even after pretreatment with levels of PMA sufficient to cause significant downregulation of protein kinase C. PMA is also ineffective in supporting the survival of cultured rodent sympathetic neurons (Rydel and Greene, 1988). Some actions of NGF have been suggested to be mediated by protein kinase C (Cremins et al., 1986; Hama et al., 1986), while other actions do not appear to require this kinase (Reinhold and Neet, 1989; Rowland-Gagné and Greene, 1990). The present findings appear to rule out a role for protein kinase $C$ in the survival mechanism of NGF, as well as of FGF, cAMP, and insulin/IGFs.

EGF had a slight effect in our assay, but this appeared to be a delay of death rather than promotion of survival. This factor has no known effects on sympathetic neurons. However, though it does not cause their differentiation, it does have a variety of actions on PC12 cells (Huff et al., 1981; Lazarovici et al., 1987), many of which are shared with NGF and with CPT-cAMP and insulin. Thus, the survival mechanism shows a degree of discrimination with respect to trophic agents.

Elevated $\mathrm{K}^{+}$was another treatment that was only slightly effective and that appeared to delay rather than prevent $\mathrm{PC} 12$ cell death. This apparently differs significantly from findings with cultured chick and rat sympathetic neurons for which NGF may be replaced with depolarizing levels of $\mathrm{K}^{+}$(Wakade et al., 1983; Koike et al., 1989). The reasons for this discrepancy are not clear, but among several alternatives could be differences in experimental paradigm. The present studies utilized newly passaged cells. Even for NGF-pretreated cells, neurites were mechanically detached before plating. In contrast, studies with rat sympathetic neurons utilized cultures first established with NGF and then switched into NGF-free medium with elevated $\mathrm{K}^{+}$without being subcultured (Koike et al., 1989). In support

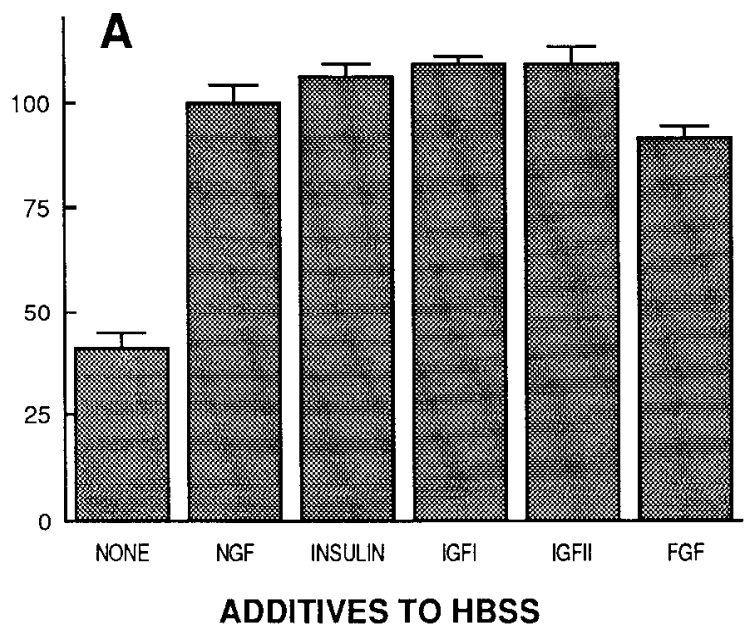

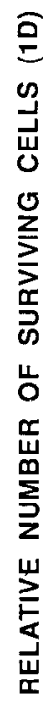

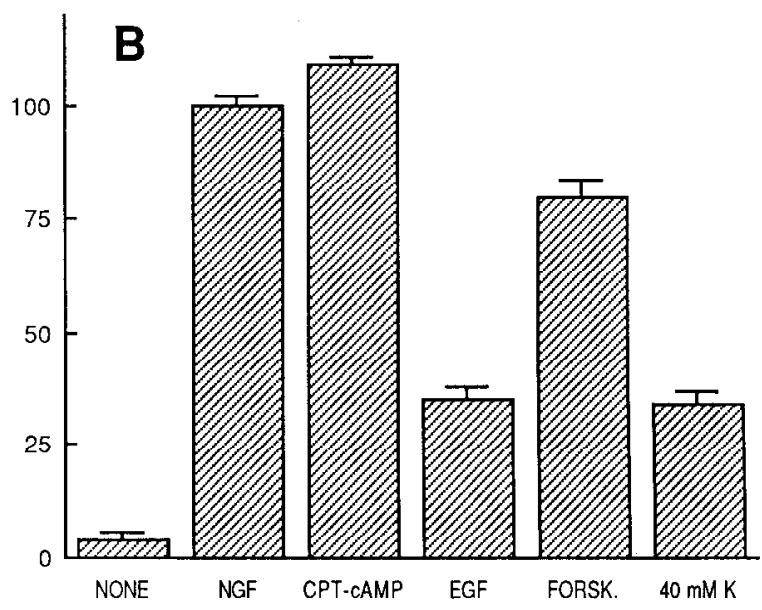

ADDITIVES TO HBSS

Figure 8. Promotion of PC12 cell survival by various agents in HBSS. Cells were washed and plated in HBSS containing the indicated agents, all as described in Materials and Methods. Concentrations here and in subsequent figures are as given in legend to Figure 5; forskolin (FORSK.) concentration was $10 \mu \mathrm{M}$. Cell counts were determined after $1 \mathrm{~d}$. The data in $A$ and $B$ represent independent experiments, and in each case cell numbers are expressed relative to those in cultures treated with NGF (average recovery in $A, 96 \%$; in $B, 104 \%$ ). Error bars represent $\operatorname{SEM}(n=3)$.

of this possible influence of experimental protocol, we have observed in preliminary experiments that well-established NGFtreated PC12 cells maintain survival and neurites when their medium is exchanged (without passaging) for scrum-free medium with 44 mм K+. Under similar circumstances, but without elevated $\mathrm{K}^{+}$, the neurites degenerate, and the cells do not survive.

Role of macromolecular synthesis. Studies with PC12 cells and neurons show that some actions of NGF require RNA transcription and that others of its actions do not (Burstein and Greene, 1978). With regard to the present study, two distinct 
Figure 9. Roles of protein kinase A $(A-C)$ and protein kinase $\mathrm{C}(D)$ in promotion of survival by various agents in serum-free RPMI 1640 medium. $A-C$, PC12 cells $(A)$ or PKA-deficient A126$1 \mathrm{~B} 2$ cells ( $B$ and $C$ ) were maintained with the indicated additives for 1 week. $D$, PC1 2 cells were pretreated for $3 \mathrm{~d}$ with or without $5 \mu \mathrm{M}$ PMA in serumcontaining medium, then washed and passaged into serum-free RPMI 1640 medium in the continued presence or absence of $5 \mu \mathrm{M}$ PMA and the indicated additives. Cell numbers were determined after $4 \mathrm{~d}$. In all cases, cell numbers are expressed relative to those in cultures treated with NGF alone (average recoveries ranged from $96 \%$ to $122 \%$ of cell numbers plated). Error bars represent $\operatorname{SEM}(n=3)$.
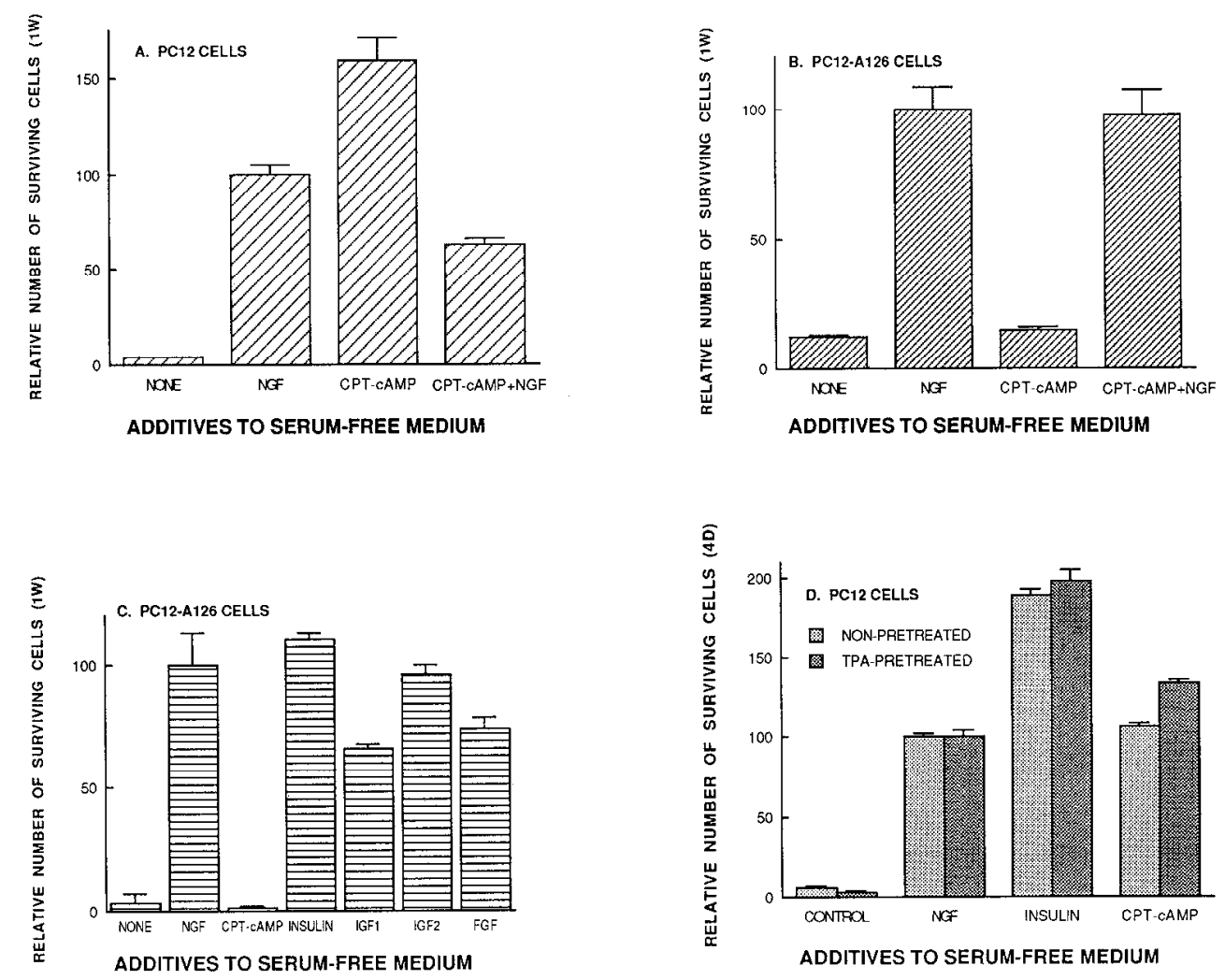

issues arise. First, does promotion of survival by NGF and other agents require macromolecular synthesis? Second, does the mechanism by which cells die in the absence of trophic support require synthesis of macromolecules?

The first issue has remained unresolved up to this time. Previous work showed that the ability of NGF to promote the

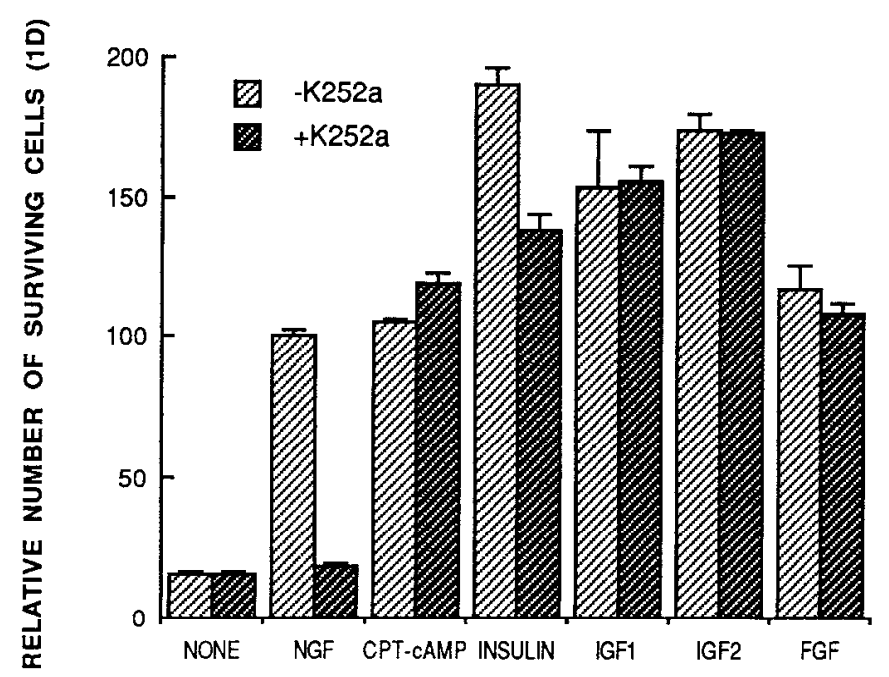

ADDITIVES TO SERUM-FREE MEDIUM

Figure 10. Effect of K-252a (200 nM) on promotion of serum-free $\mathrm{PC} 12$ cell survival by various agents. Cells were washed and plated in RPMI 1640 medium and, where appropriate, were pretreated for $2 \mathrm{hr}$ with $\mathrm{K}-252 \mathrm{a}$ before introduction of the indicated agents. Cell numbers were determined at $1 \mathrm{~d}$ and are expressed relative to those in cultures treated with NGF alone. Error bars represent SEM $(n=3)$. survival of cultured sympathetic neurons is not blocked by inhibition of RNA or protein synthesis (Partlow and Larrabee, 1971). Although these findings appeared to favor a nontranscriptional mechanism for survival maintenance by NGF, recent findings have shown that inhibitors of RNA or protein synthesis themselves prevent or delay the death of cultured sympathetic or sensory neurons even when NGF is withdrawn (Martin et al., 1988; Scott and Davies, 1990). Thus, it has not been possible to discern whether active promotion of neuronal survival by NGF requires macromolecular synthesis. The system employed herc appears to differ from that of NGF-deprived neurons. We observed that death of PC1 2 cells evoked by serum withdrawal is not prevented or significantly delayed by inhibitors of RNA or protein synthesis. The reason for this difference in susceptibility of PC12 cells and neurons to blockade of synthesis is unknown. However, because of this, it was possible here to determine directly that NGF and the other tested agents maintained PC12 cell survival even under conditions in which RNA and protein synthesis were stringently blocked. The conclusion drawn from these results is that the mechanism(s) underlying promotion of survival in the present test system does not require macromolecular synthesis.

If the mechanism whereby NGF promotes survival does not require transcription, might cell death have a transcriptional basis? The observation that inhibition of macromolecular synthesis prevents neuronal degeneration both in vitro (Martin et al., 1988; Scott and Davics, 1990) and in vivo (Oppenheim ct al., 1990) has led to the interpretation that cell death is an active process that requires RNA synthesis and that trophic factors prevent cell death by suppressing a transcription-dependent "death program." However, an alternative explanation of such observations is that cell death is caused by rapidly turning-over constitutive component(s) whose potentially lethal activities are 


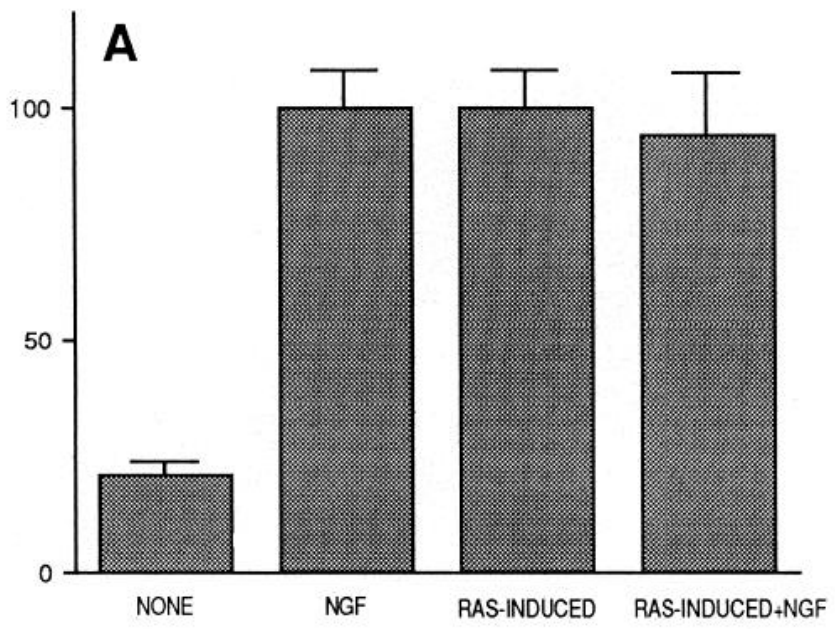

TREATMENT

号

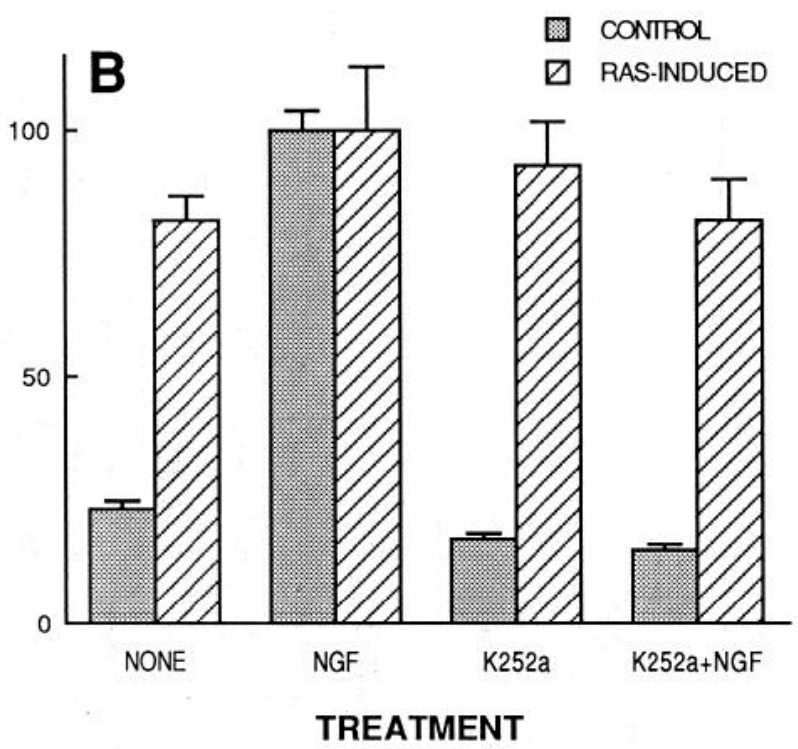

Figure 11. Effect of N-ras and NGF on serum-free survival of UR61 cells and differential effects of $\mathrm{K}-252 \mathrm{a}$ thereon. $A$, UR61 cells were pretreated for $5 \mathrm{~d}$ in the presence of $1 \mu \mathrm{M}$ dexamethasone to induce $\mathrm{N}$-ras, then washed and plated in RPMI 1640 medium in the continued presence of the dexamethasone and without or with NGF (RAS-IN$D U C E D$ and $R A S-I N D U C E D+N G F$, respectively). Equal numbers of cells without pretreatment were washed and plated in RPMI 1640 medium either without or with NGF ( $N O N E$ and $N G F$, respectively). $B$, UR61 cells with or without $6 \mathrm{~d}$ of pretreatment with dexamethasone were washed and plated in serum-free RPMI 1640. Cells with dexamethasone pretreatment continued to receive the drug. Where indicated, cultures were treated for $2 \mathrm{hr}$ with $\mathrm{K}-252 \mathrm{a}$, and following this, as indicated, NGF was added. For both $A$ and $B$, cell counts were determined after $4 \mathrm{~d}$ and are expressed relative to numbers in NGF-treated cultures. Error bars represent SEM $(n=3)$.

inhibited in the presence of trophic factors. In this case, withdrawal of a trophic factor would lead to activation of such proteins and cell degeneration, while inhibition of macromolecular synthesis would lead to their depletion and prevention or retardation of cell death. In the present work, inhibitors of

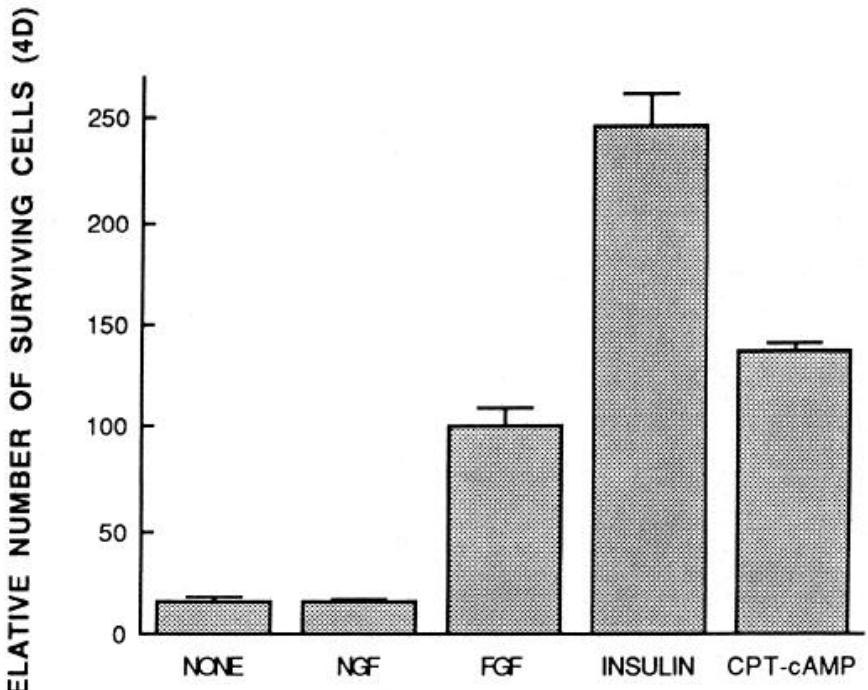

ADDITIVES TO SERUM-FREE MEDIUM

Figure 12. FGF, insulin, and CPT-cAMP prevent serum-free death of NGF-unresponsive PC12nnr5 cells. Cells were washed and cultured for $4 \mathrm{~d}$ in serum-free RPMI 1640 in presence of the indicated agents. Cell counts are expressed relative to those in cultures supplemented with FGF (average recovery, $107 \%$ of those plated). Error bars represent $\operatorname{SEM}(n=3)$.

macromolecular synthesis failed to prevent serum-free death of PC1 2 cells. This raises the possibilities either that PC12 cells, in contrast to neurons, cannot sustain long-term survival without synthesis of macromolecules, that cell death brought about by serum-deprivation and by NGF withdrawal is mediated by distinct mechanisms, or that if cell death is due to nontranscriptional regulation of constitutive proteins, then such molecules have half-lives that are longer in PC12 cells than in neurons.

In summary, our findings indicate that multiple agents can rescue PC12 cells from serum-free cell death and that these agents appear to work by means of independent primary mechanisms. These mechanisms do not require macromolecular synthesis and may be mediated, at least in part, by critical phosphorylations. The serum-free $\mathrm{PC} 12$ cell system shows many similarities to responses shown by sympathetic neurons and/or their precursors and appears to be valuable for screening potential survival agents and for uncovering the mechanisms by which trophic factors promote survival/prevent death of neurons. On the other hand, there are also several differences between the survival characteristics of $\mathrm{PC} 12$ cells and sympathetic neurons. The significance of these differences remains to be determined.

\section{References}

Aizenman Y, de Vellis J (1987) Brain neurons develop in a serum and glial free environment: effects of transferrin, insulin, insulin-like growth factor-I and thyroid hormone on neuronal survival, growth and differentiation. Brain Res 406:32-42.

Borasio GD, John J, Wittinghofer A, Barde Y-A, Sendtner M, Heumann R (1989) ras p21 protein promotes survival and fiber outgrowth of cultured embryonic neurons. Neuron 2:1087-1096.

Burstein DE, Greene LA (1978) Evidence for both RNA-synthesisdependent and -independent pathways in stimulation of neurite outgrowth by nerve growth factor. Proc Natl Acad Sci USA 75:60596063. 
Cremins J, Wagner JA, Halegoua S (1986) Nerve growth factor action is mediated by cyclic AMP- and $\mathrm{Ca}^{2+} /$ phospholipid-dependent protein kinases. J Cell Biol 103:887-893.

Czech M (1989) Signal transmission by the insulin-like growth factors. Cell 59:235-238.

Dahmer MK, Perlman RL (1988) Insulin and insulin-like growth factors stimulate deoxyribonucleic acid synthesis in $\mathrm{PC} 12$ pheochromocytoma cells. Endocrinology 122:2109-2113.

Dahmer MK, Ji-L, Perlman RL (1989) Characterization of insulinlike growth factor-I receptors in PC12 pheochromocytoma cells and bovine adrenal medulla. J Neurochem 53:1036-1042.

Doupe AJ, Patterson PII, Landis SC (1985) Small intensely fluorescent (SIF) cells in culture: role of glucocorticoids and growth factors in their development and phenotypic interconversions with other neural crest derivatives. J Neurosci 5:2143-2160.

Gammeltoft S, Ballotti R, Nielsen FC, Kowalski A, Van Obberghen E (1988) Receptors for insulin-like growth factors in the central nervous system: structure and function. Horm Metab Res 20:436-442.

Gorin PD, Johnson EM Jr (1979) Experimental autoimmune model of nerve growth factor deprivation: effects on developing peripheral sympathetic and sensory neurons. Proc Natl Acad Sci USA 76:53825386.

Green S, Rydel RE, Connolly JL, Greene LA (1986) PC12 mutants possessing low- but not high-affinity NGF receptors neither respond to, nor internalize NGF. J Cell Biol 102:830-843.

Greenberg ME, Hermanowski AL, Ziff EB (1986) Effect of protein synthesis inhibitors on growth factor activation of c-fos, c-myc, and actin gene transcription. Mol Cell Biol 6:1050-1057.

Greene LA (1978) Nerve growth factor prevents the death and stimulates neuronal differentiation of clonal PC12 pheochromocytoma cells in serum-free medium. J Cell Biol 78:747-755.

Greene LA, Tischler AS (1976) Establishment of a noradrenergic clonal line of rat adrenal pheochromocytoma cells which respond to nerve growth factor. Proc Natl Acad Sci USA 73:2424-2428.

Greene LA, Tischler AS (1982) PC12 pheochromocytoma cells in neurobiological research. Adv Cell Neurobiol 3:373-414.

Guerrero I, Pellicer A, Burstein DE (1988) Dissociation of c-fos from ODC expression and neural differentiation in a PC12 subline stably transfected with an inducible N-ras oncogene. Biochem Biophys Res Commun 150:1185-1192.

Guerrero I, Wong H, Pellicer A, Burstein DE (1986) Activated N-ras gene induces neuronal differentiation of rat $\mathrm{PC} 12$ pheochromocytoma cells. J Cell Physiol 129:71-76.

Hagag N, Halegoua S, Viola M (1986) Inhibition of nerve growth factor induced differentiation of $\mathrm{PC} 12$ cells by microinjection of antibody to ras P21. Nature 319:680-682.

Hama T, Huang KP, GuroffG (1986) Protein kinase C as a component of a nerve growth factor-sensitive phosphorylation in PC12 cells. Proc Natl Acad Sci USA 83:2353-2357.

Horii ZI, Varon S (1977) Nerve growth factor action on membrane permeation to exogenous substrates in dorsal root ganglionic dissociates from the chick embryo. Brain Res 124:121-133.

Huff K, End D, Guroff G (1981) Nerve growth factor-induced alteration in the response of $\mathrm{PC} 12$ pheochromocytoma cells to epidermal growth factor. J Cell Biol 88:189-198.

Knusel B, Michel PP, Schwaber JS, Hefti F (1990) Selective and nonselective stimulation of central cholinergic and dopaminergic development in vitro by nerve growth factor, basic fibroblast growth factor, epidermal growth factor, insulin and the insulin-like growth factors I and II. J. Neurosci 10:558-570.

Koike T, Martin DP, Johnson EM Jr (1989) Role of $\mathrm{Ca}^{2+}$ channels in the ability of membrane depolarization to prevent neuronal death induced by trophic-factor deprivation: evidence that levels of internal $\mathrm{Ca}^{2+}$ determine nerve growth factor dependence of sympathetic ganglion cells. Proc Natl Acad Sci USA 86:6421-6425.

Koizumi S, Contreras ML, Matsuda Y, Hama T, Lazarovici P, Guroff G (1988) K-252a: a specific inhibitor of the action of nerve growth factor on PC12 cells. J Neurosci 8:715-721.

Lazarovici P, Dickens G, Kuzuya H, Guroff G (1987) Long-term, heterologous down-regulation of the epidermal growth factor receptor in PC12 cells by nerve growth factor. J Cell Biol 104:161 1-1621.

Lee PL, Johnson DE, Cousens LS, Fried VA, Williams LT (1989) Purification and complementary DNA cloning of a receptor for basic fibroblast growth factor. Science 245:57-60.
Leonard DGB, Ziff EB, Greene LA (1987) Identification and characterization of mRNAs regulated by nerve growth factor in $\mathrm{PC} 12$ cells. Mol Cell Biol 7:3156-3167.

Levi A, Biocca S, Cattaneo A, Calissano P (1988) The mode of action of nerve growth factor in PC12 cells. Mol Neurobiol 2:201-226.

Levi-Montalcini R, Angeletti PU (1963) Essential role of the nerve growth factor in the survival and maintenance of dissociated sensory and sympathetic embryonic nerve cells in vitro. Dev Biol 7:653-657.

Levi-Montalcini R, Booker B (1960) Destruction of sympathetic ganglia in mammals by an antiserum to nerve growth factor protein. Proc Natl Acad Sci USA 46:384-391.

Maher PA (1988) Nerve growth factor induces protein-tyrosinc phosphorylation. Proc Natl Acad Sci USA 85:6788-6791.

Martin DP, Schmidt RE, DiStefano PS, Lowry OH, Carter JG, Johnson EM Jr (1988) Inhibitors of protein synthesis and RNA prevent neuronal death caused by nerve growth factor deprivation. J Cell Biol 106:829-844.

Matthies HJG, Palfrey HC, Hirning LD, Miller RJ (1987) Down regulation of protein kinase $\mathrm{C}$ in neuronal cells: effects on neurotransmitter release. J Neurosci 7:1198-1206.

Mobley WC, Schenker A, Shooter EM (1976) Characterization and isolation of proteolytically modified nerve growth factor. Biochemistry 15:5543-5551.

Montz HP, Davis GE, Skaper SD, Manthorpe M, Varon S (1985) Tumor-promoting phorbol diester mimics two distinct neurotrophic factors. Brain Res 355:150-154.

Morrison RS, Kornblum HI, Leslie FM, Bradshaw RA (1987) Trophic stimulation of cultured neurons from neonatal rat brain by epidermal growth factor. Science 238:72-75.

Morrison RS, Sharma A, de Vellis J, Bradshaw RA (1986) Basic fibroblast growth factor supports the survival of cerebral cortical neurons in primary culture. Proc Natl Acad Sci USA 83:7537-7541.

Nielsen FC, Gammeltoft S (1988) Insulin-like growth factors are mitogens for rat pheochromocytoma PC1 2 cells. Biochem Biophys Res Commun 154:1018-1023.

Noda M, Ko M, Ogura D-G, Liu T, Amano T, Takano T, Ikawa Y (1985) Sarcoma viruses carrying ras oncogenes induce differentiation-associated properties in a neuronal cell line. Nature 318:73-75.

O'Hare T, Pilch PF (1990) Intrinsic kinase activity of the insulin receptor. Int J Biochem 22:315-324.

Oppenheim RW, Prevette D, Tytell M. Homma S (1990) Naturally occurring and induced cell death in the chick embryo in vivo requires protein and RNA synthesis: evidence for the role of cell death genes. Dev Biol 138:104-113.

Partlow LM, Larrabee ME (1971) Effects of a nerve growth factor, embryo age and metabolic inhibitors on growth of fibers and on synthesis of ribonucleic acid and protein in embryonic sympathetic ganglia. J Neurochem 18:2101-2118.

Pincus DW, DiCicco-Bloom EM, Black IB (1990) Vasoactive intestinal peptide regulates mitosis, differentiation and survival of cultured sympathetic neuroblasts. Nature 343:564-567.

Rawson C, Cosola-Smith C, Barnes D (1990) Death of serum-free mouse embryo cells caused by epidermal growth factor deprivation is prevented by cycloheximide, 12-O-tetradecanoylphorbol-13-acetate, or vanadate. Exp Cell Res 186:177-181.

Recio-Pinto E, Rechler MM, Ishii DN (1986) Effects of insulin, insulin-like growth factor-II and nerve growth factor on neurite formation and survival in cultured sympathetic and sensory neurons. $\mathbf{J}$ Neurosci 6:1211-1219.

Reinhold DS, Neet KE (1989) The lack of a role for protein kinase C in neurite extension and in the induction of ornithine decarboxylase by nerve growth factor in PC12 cells. I Biol Chem 264:3538-3544.

Rowland-Gagné E, Greene LA (1990) Multiple pathways of N-kinase activation in PC12 cells. J Neurochem 54:424-433.

Rydel RE, Greene LA (1987) Acidic and basic fibroblast growth factors promote stable neurite outgrowth and neuronal differentiation in cultures of PC12 cells. J Neurosci 7:3639-3653.

Rydel RE, Greene LA (1988) Cyclic AMP analogues promote survival and neurite outgrowth in cultures of rat sympathetic and sensory neurons independently of nerve growth factor. Proc Natl Acad Sci USA 85:1257-1261.

Scott SA, Davies AM (1990) Inhibition of protein synthesis prevents cell death in sensory and parasympathetic neurons deprived of neurotrophic factor in vitro. J Neurobiol 21:630-638. 
Soto AM, Sonnenschein C (1985) The role of estrogens on the proliferation of human breast tumor cells (MCF-7). J Steroid Biochem 23:87-94.

Stemple DL, Mahanthappa NK, Anderson DJ (1988) Basic FGF induces neuronal differentiation, cell division, and NGF dependence in chromaffin cells: a sequence of events in sympathetic development. Neuron 1:517-552.

Togari A, Dickens G, Kuzuya H, Guroff G (1985) The effect of fibroblast growth factor on PC12 cells. J Neurosci 5:307-316.

Van Buskirk R, Corcoran T, Wagner JA (1985) Clonal variants of
PC1 2 pheochromocytoma cells with defects in cAMP-dependent protein kinases induce ornithine decarboxylase in response to nerve growth factor but not to adenosine agonists. Mol Cell Biol 5:1984-1992.

Wakade AR, Edgar DA, Thoenen H (1983) Both nerve growth factor and high $\mathrm{K}^{+}$concentrations support the survival of chick embryo sympathetic neurons. Exp Cell Res 144:377-384.

Walicke P, Cowan WM, Ueno N, Baird A, Guillemin R (1986) Fibroblast growth factor promotes survival of dissociated hippocampal neurons and enhances neurite extension. Proc Natl Acad Sci USA 83:3012-3016. 